International Research Journal of Management, IT \& Social Sciences
Available online at https://sloap.org/journals/index.php/irjmis/
Vol. 9 No. 1, January 2022, pages: 97-109
ISSN: 2395-7492
https://doi.org/10.21744/irjmis.v9n1.2012

\title{
Brand Image Mediation of Product Quality and Electronic Word of Mouth on Purchase Decision
}

\author{
Agung Ratih Saraswati ${ }^{a}$ \\ I Gusti Ayu Ketut Giantari ${ }^{\text {b }}$
}

Article history:

Submitted: 18 October 2021

Revised: 09 November 2021

Accepted: 27 December 2021

\section{Keywords:}

brand image;

eWOM;

product quality;

purchase decision;

word of mouth;

\begin{abstract}
The practical implication that can be given from the findings of this study is that this study can be used as a basic model to evaluate the Samsung smartphone company's strategy for product quality, eWOM, brand image, and consumer purchase decisions. Based on the results of statistical analysis, that product quality and eWOM directly or indirectly through brand image affect consumer purchase decisions. This can be a reference for Samsung company management in making strategies to improve purchase decisions by maintaining product quality, eWOM, and brand image of Samsung smartphones. The practical implication that can be given from the findings of this study is that this study can be used as a basic model to evaluate the Samsung smartphone company's strategy for product quality, eWOM, brand image, and consumer purchase decisions. Based on the results of statistical analysis, that product quality and eWOM directly or indirectly through brand image affect consumer purchase decisions. This can be a reference for Samsung company management in making strategies to improve purchase decisions by maintaining product quality, eWOM, and brand image of Samsung smartphones. that product quality and eWOM directly or indirectly through brand image affect consumer purchase decisions.
\end{abstract}

International research journal of management, IT and social sciences (C) 2022. This is an open access article under the CC BY-NC-ND license (https://creativecommons.org/licenses/by-nc-nd/4.0/).

Corresponding author:

Agung Ratih Saraswati,

Faculty of Economics and Business, Udayana University, Denpasar, Indonesia.

Email address: agungratihsaraswati@gmail.com

\footnotetext{
Faculty of Economics and Business, Udayana University, Denpasar, Indonesia
}

Faculty of Economics and Business, Udayana University, Denpasar, Indonesia 


\section{Introduction}

The purchase decision is a decision taken by consumers in buying a product after considering various information (Widiastiti et al., 2020). Karlina \& Seminary (2015), found that the purchase decision is influenced by the product quality and the results of his research found that product quality significantly affected the purchase decision, while the research conducted Rawung et al. (2015), found different results that product quality has no significant effect on purchase decisions. Further research conducted by Akbar (2019); Widiastiti et al. (2020); Murdapa (2020), found that product quality has a positive and significant effect on purchase decisions, in line with previous research on research Hidayat et al. (2019), found the results that product quality and brand image have a positive and significant effect on purchase decisions.

Besides product quality, according to Umamy et al. (2016), purchasing decisions are also influenced by eWOM, and the results of his research found that eWOM communication as a whole has a very positive influence on purchase decisions made by consumers, while different things were found in this study. Arta \& Yasa (2019), which states that eWOM does not have a direct and significant positive effect on purchase decisions. In further research conducted by Tjhin \& Aini (2019); Kamil \& Albert (2020), states that eWOM has a significant effect on purchase decisions. These results are supported by research conducted by Diansyah \& Nurmalasari (2017), who get the results that electronic word of mouth has a positive and significant effect on purchase decisions.

Besides product quality and eWOM according to Murdapa (2020), the purchase decision is also influenced by brand image and the results of his research found that product quality has a significant influence on brand image. Further research conducted by Ekhsan (2019), found that the brand image variable has a positive and significant influence and is the largest compared to other independent variables in his research on purchase decisions. Tjahjono et al. (2021), states that brand image has a positive and significant influence on purchase decisions. In addition, research conducted by Ramadhanti \& Usman (2021); Hermiyenti \& Wardi (2019); found that there is a positive and significant influence of brand image on the purchase decision.

In research conducted by Yasa (2018), his research found that product quality has a significant effect on brand image. Further research conducted by Oktavenia \& Ardani (2018); Ridho \& Suharyono (2017); Murdapa (2020); also found that there is a positive and significant effect of product quality on brand image, this is supported by research conducted by Situmorang et al. (2017), who found that product quality had a positive and significant effect on brand image.

Research conducted by Elseidi \& El-Baz (2016); Adriani \& Sembriwing (2017); found that the electronic word of mouth variable also has a significant influence on brand image. Triani \& Nurcaya (2020), found that there is a positive and significant effect of eWOM on brand image. In addition, eWOM was found to have a positive effect on the brand image (Yunus et al., 2016), in line with this in the research conducted by Yulia \& Ekawati (2021); Gunawan et al. (2016); also found that eWOM has a positive and significant effect on brand image.

There is a discrepancy between the results of the research conducted by Karlina \& Seminary (2015) and Rawung et al. (2015), interesting for researchers to add a brand image as a mediator, according to the results of research conducted by Ridho \& Suharyono (2017), which found that there is a positive and significant effect of product quality on brand image. In another study conducted by Tjahjono et al. (2021), found that brand image also has an influence on purchase decisions and the results of his research found that there was a positive and significant influence of brand image on purchase decisions, in further research conducted by Oktavenia \& Ardani (2018); Widiastiti et al. (2020), found that brand image can mediate positively and significantly the effect of product quality on purchase decisions (Hallak, 2006; Baum et al., 2015).

There is a gap between the results of the research conducted by Kamil \& Albert (2020) and Arta \& Yasa (2019), interesting for researchers to add a brand image as a mediator, according to the results of research conducted by Triani \& Nurcaya (2020), found that eWOM has an effect on brand image and the results of the study found that eWOM has a positive and significant effect on brand image. In addition, research conducted by Ramadhanti \& Usman (2021); Hermiyenti \& Wardi (2019), found that there is a positive and significant influence of brand image on the purchase decision. Further research conducted by Yunus et al. (2016), found that brand image can mediate positively and significantly the effect of eWOM on purchase decisions. 
Literature review and hypotheses development

Karlina \& Seminary (2015), in their research, found that product quality has a positive effect on purchase decisions. Research conducted by Nuraini (2015), entitled the effect of product quality on purchase decisions through brand image, the results show that product quality has a direct effect on brand image. Further research conducted by Akbar (2019); Widiastiti et al. (2020); Murdapa (2020), found that product quality has a positive and significant influence on purchase decisions, further research Hidayat et al. (2019), found results that product quality, price perception, and brand image have a positive and significant effect on purchasing decisions.

H1: Product quality has a positive and significant effect on purchase decisions.

Research conducted by Umamy et al. (2016), found that eWOM communication as a whole has a very positive influence on purchase decisions. Tjhin \& Aini (2019); Kamil \& Albert (2020), states that eWOM has a significant effect on purchase decisions. Elseidi \& El-Baz (2016), in their research, states that eWOM affects purchase decisions. In research conducted by Diansyah \& Nurmalasari (2017), the results show that electronic word of mouth (eWOM) has a positive and significant effect on purchase decisions.

H2: Electronic word of mouth has a positive and significant effect on purchase decisions.

Research conducted by Murdapa (2020), found that product quality has a significant effect on brand image. Further research conducted by Oktavenia \& Ardani (2018); Ridho \& Suharyono (2017), found that there is a positive and significant effect of product quality on brand image. Situmorang et al. (2017), states that product quality has a positive and significant effect on brand image.

H3: Product quality has a positive and significant effect on brand image.

Study Adriani \& Sembriwing (2017), found that the electronic word of mouth variable has a significant effect on brand image. Elseidi \& El-Baz (2016), get the results of research that eWOM is proven to affect brand image. Research conducted by Triani \& Nurcaya (2020), states that there is a positive and significant effect of eWOM on brand image. Yunus et al. (2016), found eWOM to have a positive effect on brand image. In research conducted by Yulia \& Ekawati (2021); Gunawan et al. (2016); found that eWOM has a positive and significant effect on brand image.

H4: Electronic word of mouth positive and significant effect on brand image.

Research result Murdapa (2020), shows that product quality and brand image affect the purchase decision. Research conducted by Ekhsan (2019), found that the brand image variable has a positive and significant influence and is the largest compared to other independent variables in his research on purchase decisions. Tjahjono et al. (2021), states that brand image has a positive and significant influence on purchase decisions. In addition, research conducted by Ramadhanti \& Usman (2021); Hermiyenti \& Wardi (2019); found that there is a positive and significant influence between brand image and purchase decision.

H5: Brand image has a positive and significant effect on purchase decisions.

In research Karlina \& Seminary (2015), found results that product quality has a positive influence on consumer purchase decisions, while the research conducted Rawung et al. (2015), found that product quality has no significant effect on purchase decisions. In further research conducted by Ridho \& Suharyono (2017), found that product quality has an influence on brand image, and the results of the research show that there is a positive and significant effect of product quality on brand image. In another study conducted by Tjahjono et al. (2021), found that brand image also has an influence on purchase decisions and the results of his research found that there was a positive and significant influence of brand image on purchase decisions. Further research conducted by Oktavenia \& Ardani (2018); Widiastiti et al. (2020); found that brand image can mediate positively and significantly the effect of product quality on purchase decisions.

H6: Brand image can mediate positively and significantly the effect of product quality on purchase decisions.

On research Tjhin \& Aini (2019); Kamil \& Albert (2020); found that eWOM has a significant effect on purchase decisions, while Arta \& Yasa (2019), states that eWOM does not have a direct and significant positive effect on purchase decisions. In research conducted by Triani \& Nurcaya (2020), found that eWOM has an effect on brand image and the results of his research found that eWOM has a positive and significant influence on brand image. In addition, research conducted by Ramadhanti \& Usman (2021); Hermiyenti \& Wardi (2019), found that there is a positive and

Saraswati, A. R., \& Giantari, I. G. A. K. (2022). Brand image mediation of product quality and electronic word of mouth on purchase decision. International Research Journal of Management, IT and Social Sciences, 9(1), 97-109. https://doi.org/10.21744/irjmis.v9n1.2012 
significant influence of brand image on the purchase decision. Further research conducted by Yunus et al. (2016), found that brand image can mediate positively and significantly the effect of eWOM on purchase decisions.

H7: Brand image can mediate positively and significantly the influence of electronic word of mouth to purchase decisions.

\section{Materials and Methods}

The research was conducted in Denpasar City, with the distribution of questionnaires carried out for 5 working days starting on August 2 to August 6, 2018. The distribution of the questionnaires was carried out using a google form because the research was carried out during the implementation of the Covid-19 pandemic emergency community activity restrictions (PPKM). The population of this study is Samsung smartphone consumers in Denpasar. Due to its flexibility, which means that every consumer can buy and use a Samsung smartphone anywhere, Samsung smartphone user data cannot be grouped based on certain regions, so that the data on Samsung smartphone consumers in Denpasar cannot be known with certainty (infinite). The sampling method used is non-probability sampling with purposive sampling method, namely the sampling technique using certain considerations. The criteria for determining the sample in this study are as follows:

1) Respondents live in Denpasar City;

2) Respondents are at least 18 years old;

3) Purchase and use Samsung for at least one year of use;

4) Have read more than two Samsung product reviews.

The data collection technique used is a questionnaire. Based on the conceptual model built and the relationship between the variables, the inferential statistics used to process the data is Partial Least Square (PLS) with Smart PLS Version 3.0 program. So PLS is used to determine the complexity of the relationship between latent variables and their indicators. Data analysis and structural equation modeling using PLS software.

\section{Results and Discussions}

\section{Inferential statistical analysis}

The model testing uses a variance-based or component-based approach with the Partial Least Square (PLS) method. In PLS the structural model of the relationship between latent variables is called the inner model, while the measurement model is called the outer model. The stability of this estimate is evaluated by using the $t$-statistical test, before analyzing it, the empirical research model is tested first. The test results can be described as follows: 


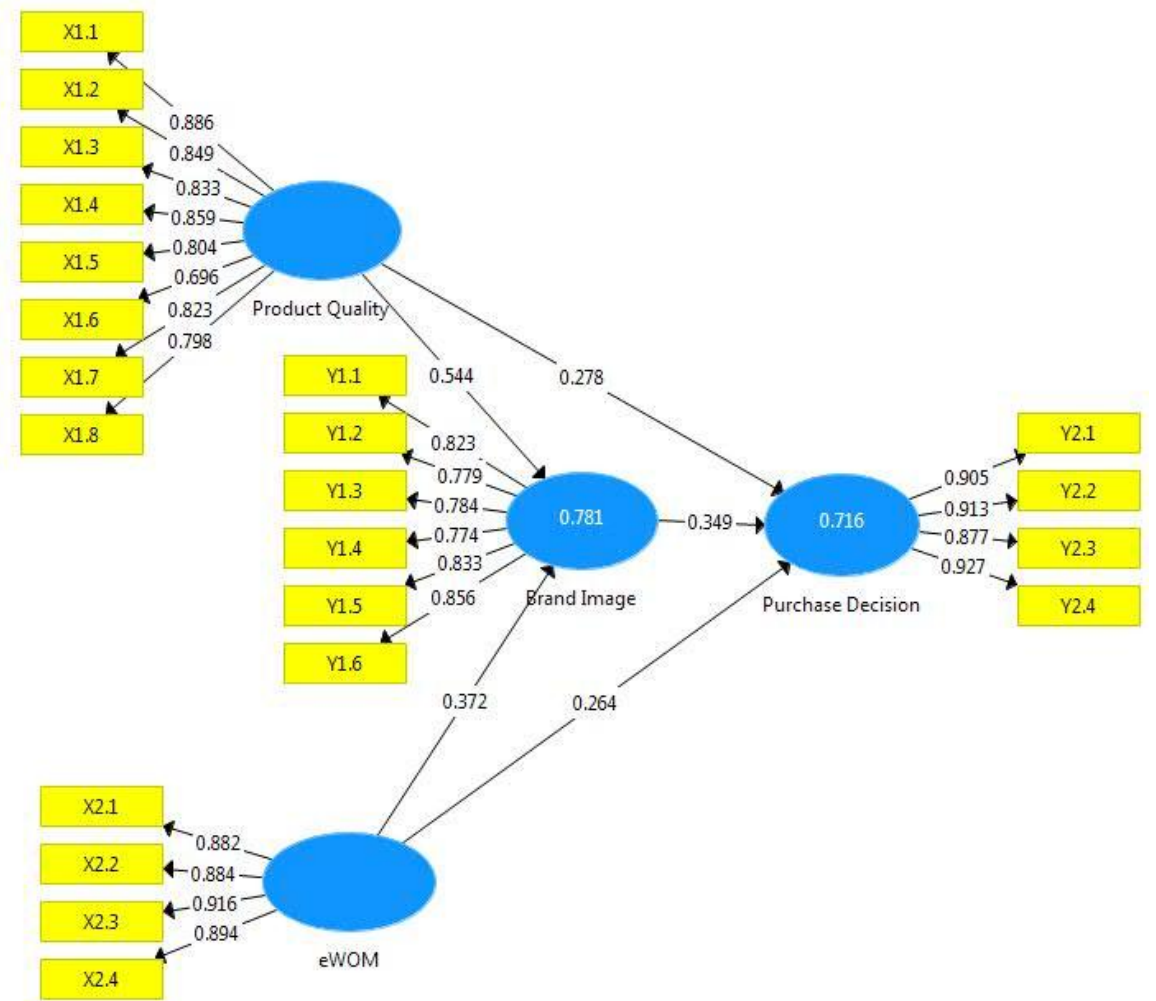

Figure 1. PLS analysis results

The goodness of Fit - Outer Model

Three values must be considered at this stage, namely the value of convergent validity, discriminant validity, and composite reliability. Convergent validity is used to determine instrument items that can be used as indicators of all latent variables. The results of this test are measured based on the value of the factor loading (outer loading) of the construct indicator. The following results of the convergent validity test are presented in Table 1.

Table 1

Test result convergent validity

\begin{tabular}{|c|c|c|c|c|}
\hline \multirow{3}{*}{$\begin{array}{l}\text { Variable } \\
\text { Product Quality } \\
\text { (X1) }\end{array}$} & \multicolumn{2}{|c|}{ Indicator } & \multirow{2}{*}{$\begin{array}{c}\begin{array}{c}\text { outer } \\
\text { Loading }\end{array} \\
0.886\end{array}$} & \multirow{2}{*}{$\begin{array}{c}\text { Information } \\
\text { Valid }\end{array}$} \\
\hline & Performance & $\mathrm{X} 1.1$ & & \\
\hline & Features & $\mathrm{X} 1.2$ & 0.849 & Valid \\
\hline & Reliability & $\mathrm{X} 1.3$ & 0.833 & Valid \\
\hline & Conformance & X1.4 & 0.859 & Valid \\
\hline & Durability & $\mathrm{X} 1.5$ & 0.804 & Valid \\
\hline & Service Ability & $\mathrm{X} 1.6$ & 0.696 & Valid \\
\hline & Aesthetics & $\mathrm{X} 1.7$ & 0.823 & Valid \\
\hline & Perveived Quality & $\mathrm{X} 1.8$ & 0.798 & Valid \\
\hline Electronic word of & Relevance & $\mathrm{X} 2.1$ & 0.882 & Valid \\
\hline mouth (X2) & Comprehensiveness & $\mathrm{X} 2.2$ & 0.884 & Valid \\
\hline & Accuracy & $\mathrm{X} 2.3$ & 0.916 & Valid \\
\hline & Timeliness & $\mathrm{X} 2.4$ & 0.894 & Valid \\
\hline Brand image (Y1) & Product Attributes & Y1.1 & 0.823 & Valid \\
\hline
\end{tabular}

Saraswati, A. R., \& Giantari, I. G. A. K. (2022). Brand image mediation of product quality and electronic word of mouth on purchase decision. International Research Journal of Management, IT and Social Sciences, 9(1), 97-109. https://doi.org/10.21744/irjmis.v9n1.2012 


\begin{tabular}{llccc}
\hline Variable & \multicolumn{1}{c}{ Indicator } & & $\begin{array}{c}\text { outer } \\
\text { Loading }\end{array}$ & Information \\
\hline \multirow{4}{*}{$\begin{array}{llll}\text { Consumer Benefits } \\
\text { Brand Personality }\end{array}$} & Y 1.2 & 0.779 & Valid \\
& User Imagery & Y 1.3 & 0.784 & Valid \\
& $\begin{array}{l}\text { Organizational Association } \\
\text { Brand-Customer }\end{array}$ & Y 1.4 & 0.774 & Valid \\
& Relationship & Y 1.6 & 0.833 & Valid \\
& & & 0.856 & Valid \\
Purchase decision & Attractiveness & Y2.1 & 0.905 & Valid \\
(Y2) & Brand Selection & Y 2.2 & 0.913 & Valid \\
& Needs & Y 3.3 & 0.877 & Valid \\
& Brand Trust & Y 4.4 & 0.927 & Valid \\
\hline
\end{tabular}

Primary Data, 2021

In Table 1 it can be seen that the product quality variable, all of its indicators have a factor loading value above 0.5 with the highest indicator value found in the performance indicator (X1.1), Samsung smartphone products make it easier for users to complete work with the respondent's perceived value of 0.886 . This shows that the performance of Samsung smartphone products that make it easier for consumers to get work done is an important reason for consumers in choosing smartphones which they will use.

When viewed on the electronic word of mouth variable, all of the indicators also have a factor loading value above 0.5 with the highest indicator value found in the accuracy indicator. (X.2.3), with the respondent's perceived value of 0.916. This reflects that products Samsung smartphones able to convince consumers about the reliability of products and services will become the antecedent of electronic word of mouth, which is an important reason for consumers to buy product smartphone Samsung.

The entire value of the brand image indicator can also form the brand image variable because the brand image variable indicator has a value greater than 0.5. Brand-customer relationship indicator (Y1.6), consumers trust smartphone products Samsung can create relationships with consumers has the highest factor loading value, with an average respondent's perceived value of 0.856 . This illustrates that the indicator is dominant in representing the brand image variable. In addition, this condition reflects that most users buy smartphones because of the good brand image of smartphone companies.

The factor loading value of the purchase decision indicator shows that the four indicators significantly form the consumer purchase decision variable (O'Cass, 2000; Yoon, 2002). Brand selection indicator (Y2.2), consumers who choose to buy Samsung smartphone products from various alternatives is an indicator that has the highest factor loading, with a perceived value of 0.913 . Test results Table 5.8 shows that all outer loading has a value greater than 0.5 , so this measurement can be explained that it has met the requirements of convergent validity.

The validity test was also carried out by comparing the value of the square root of average variance extract (AVE) on each construct with the correlation between other constructs contained in the model. The results of the discriminant validity test are presented in Table 5.9 which explains that the AVE value in the research variable has a value above 0.5 so that this measurement can be explained as meeting the requirements of discriminant validity measurement.

Table 2

Test result discriminant validity

\begin{tabular}{lcc}
\hline Variable & AVE & Information \\
\hline Product Quality & 0.654 & Valid \\
Electronic word of mouth & 0.673 & Valid \\
Brand image & 0.820 & Valid \\
Purchase decision & 0.800 & Valid \\
\hline
\end{tabular}

Primary Data, 2021

Furthermore, composite reliability testing is carried out which aims to test the reliability of the instrument in a research model. Based on Table 2, it can be explained that the results of the composite reliability test are good, because all of 
the latent variables are reliable, which have a composite reliability value greater than 0.7 . This shows that all indicators have become measuring instruments for their respective constructs.

Table 3

Test result composite reliability

\begin{tabular}{lcc}
\hline Variable & Composite Reliability & Information \\
\hline Product Quality & 0.919 & Reliable \\
Electronic word of mouth & 0.942 & Reliable \\
Brand image & 0.948 & Reliable \\
Purchase decision & 0.941 & Reliable
\end{tabular}

Primary Data, 2021

The last step after testing composite reliability is testing Cronbach's alpha value. The test results in Table 3 show that all latent variables have Cronbach's alpha values above 0.7 so it can be concluded that this study has met the reliability.

Table 4

Test result Cronbach's Alpha

\begin{tabular}{lcc}
\hline Variable & Composite Reliability & Information \\
\hline Product Quality & 0.894 & Reliable \\
Electronic word of mouth & 0.930 & Reliable \\
Brand image & 0.927 & Reliable \\
Purchase decision & 0.917 & Reliable \\
\hline
\end{tabular}

Primary Data, 2021

The goodness of Fit - Inner Model (Structural Model)

The goodness of fit structural inner model describes the relationship between latent variables based on substantive theory. Assessing the model with PLS begins by looking at the R-square for each endogenous latent variable. The results of the inner model test can see the relationship between constructs by comparing the significant value and $\mathrm{R}-$ square of the research model. The R2 value of each endogenous variable in this study can be seen in Table 4 . The R2 value of the purchase decision variable of 0.716 means that $71.6 \%$ of the variation in the purchase decision variable is explained by the product quality, electronic word of mouth, brand image, and purchase decision variables used in the model, while the remaining $28.4 \%$ is explained by variables or other factors outside the model.

Table 4

Endogenous Variable $\mathrm{R}^{2}$ Value

\begin{tabular}{lc}
\hline Endogenous Variables & R-Square \\
\hline Brand image I (Y1) & 0.781 \\
Purchase decision (Y2) & 0.716 \\
\hline
\end{tabular}

Primary Data, 2021

The goodness of fit model structural the inner model is tested using the predictive-relevance value (Q2), to measure how well the observation value is produced by the model and also the parameter estimates, meaning how much influence the exogenous variable has on the endogenous variable so that only the endogenous variable has a $Q^{2}$ value. Predictive value - relevance is obtained by the formula:

$$
\mathrm{Q}^{2}=1-\left(1-\mathrm{R} 1^{2}\right)\left(1-\mathrm{R} 2^{2}\right)=1-(1-0.781)(1-0.716)=0.9378
$$

Saraswati, A. R., \& Giantari, I. G. A. K. (2022). Brand image mediation of product quality and electronic word of mouth on purchase decision. International Research Journal of Management, IT and Social Sciences, 9(1), 97-109. https://doi.org/10.21744/irjmis.v9n1.2012 
The results above show the predictive-relevance value of 0.9378 , thus the value is $>0$. The $\mathrm{Q}^{2}$ value is close to the value 1 , which means the model has a predictive-relevance value, and it can be stated that this structural model fits the data.

\section{Hypothesis testing results}

Hypothesis testing is done by using the $\mathrm{p}$ test ( $\mathrm{p}$-value) on each path of influence between variables. In PLS statistical testing of each hypothesized relationship is carried out using simulation. Testing with bootstrapping is also intended to minimize the problem of abnormal research data.

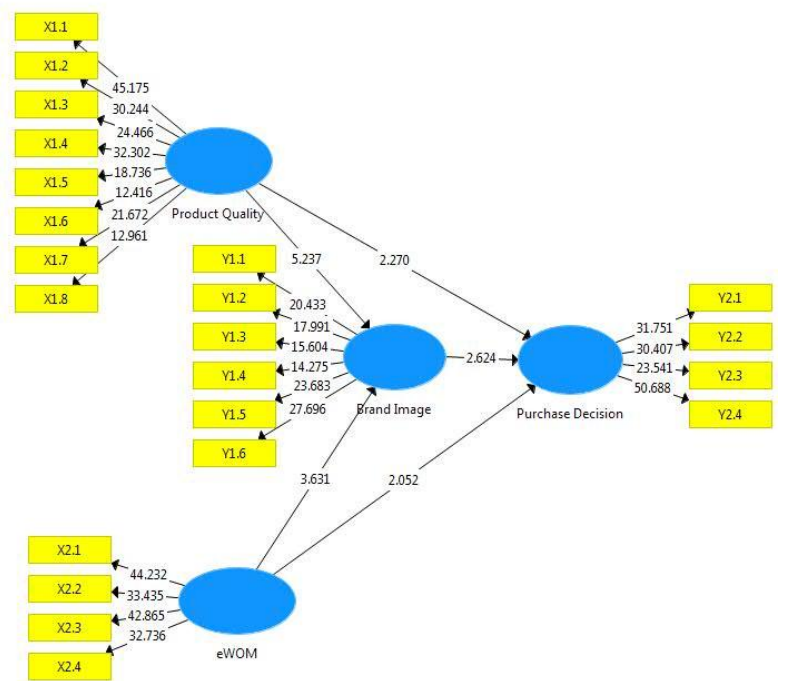

Figure 2. PLS Analysis Bootstrapping Results

The results of the bootstrapping test from the PLS analysis can be seen in Table 5. It has been determined previously that the t-table value with a significance of five percent is 1.96 .

Table 5

Inner Loading Results

\begin{tabular}{|c|c|c|c|c|c|}
\hline Variable & $\begin{array}{l}\text { Original } \\
\text { Sample } \\
(\mathrm{O})\end{array}$ & $\begin{array}{l}\text { Sample } \\
\text { mean } \\
(\mathrm{M})\end{array}$ & $\begin{array}{l}\text { Standard } \\
\text { Deviation } \\
\text { (STDEV) }\end{array}$ & $\begin{array}{c}\text { t-statistics } \\
(|\mathrm{O} / \mathrm{STDEV}|)\end{array}$ & p-value \\
\hline $\begin{array}{l}\text { Product Quality } \\
\text { Purchase decision }\end{array} \rightarrow$ & 0.278 & 0.282 & 0.122 & 2.270 & 0.024 \\
\hline $\begin{array}{l}\text { eWOM } \rightarrow \\
\text { Purchase decision }\end{array}$ & 0.264 & 0.265 & 0.129 & 2.052 & 0.041 \\
\hline $\begin{array}{l}\text { Product Quality } \rightarrow \\
\text { Brand image }\end{array}$ & 0.544 & 0.555 & 0.104 & 5.237 & 0.000 \\
\hline $\begin{array}{l}\text { eWOM } \rightarrow \\
\text { Brand image }\end{array}$ & 0.372 & 0.363 & 0.103 & 3,631 & 0.000 \\
\hline $\begin{array}{l}\text { Brand image } \rightarrow \\
\text { Purchase decision }\end{array}$ & 0.349 & 0.345 & 0.133 & 2,624 & 0.009 \\
\hline $\begin{array}{l}\text { Product Quality } \rightarrow \\
\text { Brand image } \rightarrow\end{array}$ & 0.190 & 0.192 & 0.084 & 2.273 & 0.023 \\
\hline $\begin{array}{l}\text { Purchase decision } \\
\text { eWOM } \rightarrow \\
\text { brand image } \rightarrow \text { Purchase } \\
\text { decision }\end{array}$ & 0.130 & 0.125 & 0.060 & 2.167 & 0.031 \\
\hline
\end{tabular}


Effect of product quality on purchase decision

Table 5 provides information that product quality shows a positive and significant effect on purchase decisions indicated by the path coefficient with a value of 0.278 with a t-statistic of $2.270(<1.96)$. The results of this test indicate that Hypothesis 1 (H1) states that product quality has a positive and significant effect on purchase decision provable. This shows that the increase in product quality can improve purchase decisions for consumers in real.

Product quality has a positive and significant effect on purchase decisions, it means that the better product quality received by Samsung consumers, the higher the purchase decision on Samsung smartphones. Vice versa, the lower the product quality received by Samsung smartphone consumers, the lower the purchase decision on Samsung smartphones will be. The test results show that very good product quality has implications for very high purchase decisions on Samsung smartphones, due to the ability of Samsung smartphones to maintain performance which makes it easier for users to complete their work and maintain the Samsung smartphone brand so that it is always the choice of smartphone consumers.

Based on this, it has implications for very high purchase decisions on Samsung smartphones which are marked by very high consumer appeal and need for smartphones Samsung results of this study are in line with the research conducted Karlina \& Seminary (2015); Akroush et al., 2016; Akbar (2019); Widiastiti et al. (2020); Murdapa (2020); Hidayat et al. (2019); which states that product quality has a significant effect on purchase decisions. The results in this study are different from the research conducted by Rawung et al. (2015), which states that product quality has no significant effect on purchase decisions.

\section{Effect of eWOM on purchase decision}

Electronic word of mouth shows a positive and significant influence on the purchase decision. These results are shown in Table 5, where the path coefficient shows a value of 0.264 with a t-statistic value of 2.052 (> 1.96). This test shows that Hypothesis $2(\mathrm{H} 2)$ states that electronic word of mouth positive and significant effect on purchase decisions provable. That is, increasing electronic word of mouth will be able to significantly improve purchase decision consumers in real (Maxham III, 2001; Zhang et al., 2010).

eWOM has a positive and significant effect on purchase decisions, it means the better eWOMreceived by Samsung smartphone consumers, the higher the purchase decision on Samsung smartphones will be. Vice versa, the less good the eWOM received by Samsung smartphone consumers, the lower the purchase decision on Samsung smartphones will be. The test results show that it is very good eWOM has implications for very high purchase decisions on Samsung smartphones, due to the ability of Samsung smartphones to maintain relevance for Samsung smartphone users (Amin, 2016).

Based on this, it has implications for very high purchase decisions on Samsung smartphones which are marked by very high consumer appeal and need for smartphone Samsung. The results of this study are in line with the research conducted Tjhin \& Aini (2019); Kamil \& Albert (2020) Karlina \& Seminary (2015); Akbar (2019); Widiastiti et al. (2020); Murdapa (2020); Hidayat et al. (2019); Diansyah \& Nurmalasari (2017); which state that eWOM has a significant effect on purchase decisions. The results in this study are different from the research conducted by Arta \& Yasa (2019), which states that eWOM has no significant effect on purchase decisions.

\section{Effect of product quality on brand image}

Product quality shows a positive and significant influence on brand image, where the path coefficient shows a value of 0.544 with a t-statistic of 5.237 (> 1.96). The results of this test give meaning to accept Hypothesis 3 (H3) which states that product quality is a positive and significant effect on brand image provable. This shows that the increase in product quality will be able to significantly improve brand image in real (Cretu \& Brodie, 2007; Wu et al., 2011).

Product quality has a positive and significant effect on brand image, it means that the better product quality received by Samsung smartphone consumers, the better consumer views of the brand image on Samsung smartphones will be. Vice versa, the less good the product quality received by Samsung smartphone consumers, the less good consumers' views of the brand image on Samsung smartphones will be. The test results show that very good product quality has implications for the very good view of consumers on the brand image on Samsung smartphones, due to the performance ability of Samsung smartphones to make it easier for users to complete work and the well-known Samsung smartphone brand (Mahatama \& Wardana, 2021).

Saraswati, A. R., \& Giantari, I. G. A. K. (2022). Brand image mediation of product quality and electronic word of mouth on purchase decision. International Research Journal of Management, IT and Social Sciences, 9(1), 97-109. https://doi.org/10.21744/irjmis.v9n1.2012 
Based on this, it has implications for the very high consumer view of the Samsung smartphone brand image which is marked by very high benefits received by consumers, product attributes, brand relationships with consumers, and company credibility smartphone Samsung. The results of this study are in line with the research conducted Ketut (2018); Oktavenia \& Ardani (2018); Ridho \& Suharyono (2017); Murdapa (2020); Situmorang et al. (2017); which states that product quality has a positive and significant effect on brand image.

\section{Effect of eWOM on brand image}

Electronic word of mouth shows a positive and significant influence on brand image, where the path coefficient shows a value of0.372 with a t-statistic of 3.631 (<1.96). The results of this test indicate that Hypothesis 4 (H4) states that electronic word of mouth positive and significant effect on brand image provable. This shows that the increase in electronic word of mouth can improve brand image in real (Heryana \& Yasa, 2020).

eWOM has a positive and significant effect on brand image, it means that the better eWOM received by Samsung smartphone consumers, the better the consumer's view of the brand image on Samsung smartphones. Vice versa, the less favorable the eWOM received by Samsung smartphone consumers, the less favorable the consumer's view of the brand image on Samsung smartphones will be. The test results show that eWOM is very good has implications for the very good consumer view of the brand image on Samsung smartphones due to the ability of Samsung smartphones to maintain relevance to Samsung smartphone users (Park \& Lee, 2009; Park \& Lee, 2008).

Based on this, it has implications for the very high consumer view of the Samsung smartphone brand image which is marked by very high benefits received by consumers, product attributes, brand relationships with consumers, and company credibility smartphone Samsung. The results of this study are in line with the research conducted Elseidi \& El-Baz (2016); Adriani \& Sembriwing (2017); Triani \& Nurcaya, (2020); Yunus et al. (2016); Yulia \& Ekawati (2021); Gunawan et al. (2016); which states that the quality of eWOM has a positive and significant effect on brand image.

\section{Effect of brand image on purchase decision}

Brand image shows a positive and significant influence on purchase decisions, where the path coefficient shows a value of 0.349 with a t-statistic of 2.624 (> 1.96). The results of this test give meaning to accept Hypothesis 5 (H5) which states that brand image is a positive and significant effect on purchase decisions probable. This shows that the increase in the brand image will be able to significantly improve purchase decision consumers in real.

Brand image positive and significant effect on purchase decisions, it means that the better the brand image of Samsung smartphones, the higher the purchase decisions on Samsung smartphones. Vice versa, the less good the brand image of Samsung smartphone products, the lower the purchase decision on Samsung smartphones. The test results show that a very good brand image has implications for very high purchase decisions on Samsung smartphones, due to the ability of Samsung smartphones to provide benefits for consumers, good product attributes, relationships with consumers, and maintain company credibility smartphone Samsung.

Based on this, it has implications for very high purchase decisions on Samsung smartphones which are marked by very high consumer appeal and need for smartphone Samsung. The results of this study are in line with the research conducted Murdapa (2020); Tjahjono et al. (2021); Ekhsan (2019); Ramadhanti \& Usman (2021); Hermiyenti \& Wardi (2019); which states that brand image has a significant effect on purchase decisions.

\section{Brand image mediates the effect of product quality on purchase decisions}

Brand image can positively and significantly mediate product quality on purchase decisions, where the path coefficient shows a value of 0.190 with a t-statistic of $2.273(<1.96)$. The results of this test indicate that Hypothesis 6 (H6) states that brand image positively and significantly mediates product quality on purchase decision provable. This shows that brand image able to positively and significantly mediate product quality on purchase decision in real.

Brand image can mediate influence product quality on the purchase decision, it shows that the better the product quality and the better the brand image, it will increase the purchase decision on Samsung smartphones. The test results show that the very good product quality of Samsung smartphones is marked by the very good performance of Samsung smartphones to make it easier for users to complete their work so that the brand image of Samsung smartphones remains famous as a smartphone that provides benefit to consumers, with product attributes, relationships, and good company credibility. Based on this, it has implications for very high purchase decisions on Samsung smartphones which are marked by very high consumer appeal and need for smartphone Samsung. 
The results in this study are in line with the results of research conducted by Oktavenia \& Ardani (2018); Widiastiti et al. (2020); which states that brand image can mediate positively and significantly the effect of product quality on purchase decisions. Results testing This also gives the meaning that product quality good is mediated by brand image good ones have a very high impact purchase decision on Samsung smartphones.

\section{Brand image mediates the effect of eWOM on purchase decisions}

Brand image can mediate positively and significantly electronic word of mouth to purchase decisions, where the path coefficient shows a value of 0.130 with a t-statistic of 2.167 (> 1.96). The results of this test indicate that Hypothesis 7 (H7) states that brand image able to mediate positively and significantly influence electronic word of mouth to purchase decision probable. This shows that brand image able to mediate positively and significantly electronic word of mouth to purchase decisions in real.

Brand image can mediate influence eWOMto purchase decisions. This shows that the better the eWOM and the better the brand image, the higher the purchase decision on Samsung smartphones. The test results show that the very good eWOM received by Samsung smartphone consumers is due to the ability of Samsung smartphones to maintain relevance for its users, so that the Samsung smartphone brand image remains famous as a smartphone that provides benefit to consumers, with product attributes, relationships, and good company credibility. Based on this, it has implications for the very high purchase decision on Samsung smartphones. marked by very high consumer appeal and need for smartphone Samsung (Park \& Lee, 2009; Gruen et al., 2006).

The results in this study are in line with the results of research conducted by Yunus et al. (2016), which states that brand image can mediate positively and significantly the effect of eWOM on purchase decisions. Results testing This also means that a good eWOM mediated by a good brand image has a very high impact on purchase decisions on Samsung smartphones.

\section{Conclusion}

The results of the study explain that product quality is an important variable that has a positive and significant effect on purchase decisions, either directly or indirectly through the mediating variable brand image. Thus, these results can be used as material for consideration and input for strategic policymakers in determining the appropriate promotional model to market Samsung smartphones. In terms of eWOM, either directly or indirectly through the mediating variable brand image becomes the antecedent of purchase decisions on Samsung smartphones. This can be a consideration for company management to emphasize eWOM in marketing products to users or the target market of Samsung smartphones. Future research is expected to be able to integrate other variables such as price, purchase intention, or smartphone user loyalty so that it can become information as consideration for the Samsung smartphone company in setting the price of smartphone products and as a consideration for consumers before buying a smartphone and in further research to use different analytical techniques like moderation.

\section{Conflict of interest statement}

The authors declared that they have no competing interests.

\section{Statement of authorship}

The authors have a responsibility for the conception and design of the study. The authors have approved the final article.

Acknowledgments

We are grateful to two anonymous reviewers for their valuable comments on the earlier version of this paper.

Saraswati, A. R., \& Giantari, I. G. A. K. (2022). Brand image mediation of product quality and electronic word of mouth on purchase decision. International Research Journal of Management, IT and Social Sciences, 9(1), 97-109. https://doi.org/10.21744/irjmis.v9n1.2012 


\section{References}

Adriani, N., \& Sembriwing, B. K. (2017). Analisis Strategi Merek Dan Citra Merek Terhadap Keputusan Pembelian Pada J.co Donuts \& Coffee Cabang Cambridge City Square Medan. Media Informasi Manajemen, 1(2), 1-12.

Akbar, M. F. (2019). The Influence of Product Quality and Price on Purchasing Decisions at Mitraindo South Tangerang Online Shop. Jurnal Ad'ministrare, 6(2), 237-248.

Akroush, M. N., Jraisat, L. E., Kurdieh, D. J., AL-Faouri, R. N., \& Qatu, L. T. (2016). Tourism service quality and destination loyalty-the mediating role of destination image from international tourists' perspectives. Tourism Review.

Amin, M. (2016). Internet banking service quality and its implication on e-customer satisfaction and e-customer loyalty. International journal of bank marketing.

Arta, I. G. S., \& Yasa, N. N. K. (2019). The role of purchase intention on mediating the relationship of e-WOM and eWOM credibility to purchase decision. Russian Journal of Agricultural and Socio-Economic Sciences, 2(86), 3339.

Baum, C., El-Tohamy, W., \& Gruda, N. (2015). Increasing the productivity and product quality of vegetable crops using arbuscular mycorrhizal fungi: a review. Scientia horticulturae, 187, 131-141. https://doi.org/10.1016/j.scienta.2015.03.002

Cretu, A. E., \& Brodie, R. J. (2007). The influence of brand image and company reputation where manufacturers market to small firms: A customer value perspective. Industrial marketing management, 36(2), 230-240. https://doi.org/10.1016/j.indmarman.2005.08.013

Diansyah, D., \& Nurmalasari, A. I. (2017). Pengaruh Pemasaran Internet Dan Electronic Word of Mouth Terhadap Keputusan Pembelian Dengan Kesadaran Merek Sebagai Variabel Intervening Pada Mahasiswa Universitas 17 Agustus 1945 Jakarta. Journal Of Business Studies, 2(1), 84-98.

Ekhsan, M. (2019). The influence job satisfaction and organizational commitment on employee turnover intention. Journal of Business, Management, \& Accounting, 1(1).

Elseidi, R. I., \& El-Baz, D. (2016). Electronic word of mouth effects on consumers' brand attitudes, brand image and purchase intention: an empirical study in Egypt. The Business \& Management Review, 7(5), 268.

Gruen, T. W., Osmonbekov, T., \& Czaplewski, A. J. (2006). eWOM: The impact of customer-to-customer online know-how exchange on customer value and loyalty. Journal of Business research, 59(4), 449-456. https://doi.org/10.1016/j.jbusres.2005.10.004

Gunawan, A., Diana, B., Muchardie, B. G., \& Sitinjak, M. F. (2016). The effect of involvement and Electronic Word of Mouth (eWOM) on brand image and its impact on consumers brand switching of Mamypoko. International Journal of Economics and Management, 10(1), 19-31.

Hallak, J. C. (2006). Product quality and the direction of trade. Journal of international Economics, 68(1), $238-265$. https://doi.org/10.1016/j.jinteco.2005.04.001

Hermiyenti, S., \& Wardi, Y. (2019). A literature review on the influence of promotion, price and brand image to purchase decision. In 2nd Padang International Conference on Education, Economics, Business and Accounting (PICEEBA-2 2018) (pp. 254-261). Atlantis Press.

Heryana, D. K., \& Yasa, N. N. K. (2020). Effect of electronic word of mouth on repurchase intention mediated by brand attitude. International Research Journal of Management, IT and Social Sciences, 7(2), 9-20. https://doi.org/10.21744/irjmis.v7n2.854

Hidayat, A., Triyani, D., \& Prapti, L. (2019). The Influence Of Product Quality, Price Perception, And Brand Image On Furniture Purchase At PT. Jati City Furindo Jepara. Economics and Business Solutions Journal, 3(2), 67-80.

Kamil, N. A. I., \& Albert, A. (2020). The effect of e-wom and brand image towards Sushi Masa consumer purchasing decision. Journal of Social Studies (JSS), 16(1), 19-34.

Karlina, N., Putu, N., \& Seminari, N. K. (2015). Pengaruh Citra Merek Dan Kualitas Produk Terhadap Keputusan Pembelian Produk PT. Karya Pak Oles Tokcer Denpasar (Doctoral dissertation, Udayana University).

Ketut, Y. I. (2018). The role of brand image mediating the effect of product quality on repurchase intention. Russian Journal of Agricultural and Socio-Economic Sciences, 83(11).

Mahatama, A. A. B. P., \& Wardana, M. (2021). The role of brand image and customer commitment in mediating service quality towards customer loyalty. International Research Journal of Management, IT and Social Sciences, 9(1), 79-89. https://doi.org/10.21744/irjmis.v9n1.2006

Maxham III, J. G. (2001). Service recovery's influence on consumer satisfaction, positive word-of-mouth, and purchase intentions. Journal of business research, 54(1), 11-24. https://doi.org/10.1016/S0148-2963(00)00114-4 
Murdapa, P. (2020). The Effect of Price, Product Design, Product Quality and Brand Image on Purchase Decisions. In EBGC 2019: Proceedings of the 2nd International Conference on Economics, Business, and Government Challenges, EBGC 2019, 3 October, UPN" Veteran" East Java, Surabaya, Indonesia (p. 74). European Alliance for Innovation.

Nuraini, A. (2015). Pengaruh celebrity endorser dan kualitas produk terhadap keputusan pembelian melalui citra merek pada kosmetik wardah di kota semarang (Doctoral dissertation, UNIVERSITAS NEGERI SEMARANG).

O'Cass, A. (2000). An assessment of consumers product, purchase decision, advertising and consumption involvement in fashion clothing. Journal of economic psychology, 21(5), 545-576. https://doi.org/10.1016/S01674870(00)00018-0

Oktavenia, K. A. R., \& Ardani, I. G. A. K. S. (2018). Pengaruh Kualitas Produk Terhadap Keputusan Pembelian Handphone Nokia Dengan Citra Merek Sebagai Pemediasi. E-Jurnal Manajemen Universitas Udayana, 8(3), 1374.

Park, C., \& Lee, T. M. (2009). Information direction, website reputation and eWOM effect: A moderating role of product type. Journal of Business research, 62(1), 61-67. https://doi.org/10.1016/j.jbusres.2007.11.017

Ramadhanti, S., \& Usman, O. (2021). Influence of Brand Ambassador BTS, Brand Image, and Product Quality on Tokopedia E-Commerce Purchase Decision.

Rawung, D. R., Oroh, S. G., \& Sumarauw, J. S. (2015). Analisis Kualitas produk, merek dan harga terhadap keputusan pembelian sepeda motor Suzuki Pada PT. Sinar Galesong Pratama Manado. Jurnal EMBA: Jurnal Riset Ekonomi, Manajemen, Bisnis dan Akuntansi, 3(3).

Ridho, M., \& Suharyono, S. (2017). Pengaruh Kualitas Produk Terhadap Brand Image dan Dampaknya Pada Kepuasan Pelanggan (Survei pada Pelanggan kartu prabyar Simpati, Kota Malang). Jurnal Administrasi bisnis, 53(1), 124131.

Situmorang, I. L., Jushermi, J., \& Marhadi, M. (2017). Pengaruh Kualitas Produk dan Iklan terhadap Citra Merek dan Keputusan Pembelian Produk Kecantikan Merek Pond's pada Remaja di Kota Pekanbaru (Doctoral dissertation, Riau University).

Tjahjono, E. J., Ellitan, L., \& Handayani, Y. I. (2021). Product Quality And Brand Image Towards Customers'satisfaction Through Purchase Decision Of Wardah Cosmetic Products In Surabaya. Journal of Entrepreneurship \& Business, 2(1), 56-70.

Tjhin, V. U., \& Aini, S. R. N. (2019). Effect of E-WOM and social media usage on purchase decision in Clothing Industry. In Proceedings of the 2019 5th International Conference on E-business and Mobile Commerce (pp. 3034).

Triani Wahyuni Dewi, N. K., dan Nurcaya, I. N. (2020). Open Access The Role of Brand image Mediates the Effect of Electronic Word of Mouth on NMAX Purchase Intention in Tabanan City. American Journal of Humanities and Social Sciences Research (AJHSSR), 4(3), 406-417.

Umamy, C., Kumadji, S., \& Yulianto, E. (2016). Pengaruh Electronic Word of Mouth Terhadap Brand Image Serta Dampaknya Pada Minat Beli (Survei Pada Mahasiswa Universitas Brawijaya Malang Angkatan 2015/2016 Pengguna Smartphone). Jurnal Administrasi Bisnis, 33(1), 114-119.

Widiastiti, N. M. G., Yasa, N. N. K., \& Rahanata, G. B. (2020). The Role of Brand Image In Mediating The Relationship of Product Quality And Price Fairness With Purchase Decision (A Case Study of the IPhone Product in Denpasar City). International Journal of Economics and Management Studies, 7(4), 199-207.

Wu, P. C., Yeh, G. Y. Y., \& Hsiao, C. R. (2011). The effect of store image and service quality on brand image and purchase intention for private label brands. Australasian Marketing Journal (AMJ), 19(1), 30-39. https://doi.org/10.1016/j.ausmj.2010.11.001

Yoon, S. J. (2002). The antecedents and consequences of trust in online-purchase decisions. Journal of interactive marketing, 16(2), 47-63. https://doi.org/10.1002/dir.10008

Yulia, I. G. A. A., \& Ekawati, N. W. (2021). The Role of Brand Image Mediates the Influence of Credibility of Celebrity Endorser and EWOM on Customer Loyalty in Shopping at the Shopee Marketplace.

Yunus, N. H., Md Ariff, M. S., Mohd Som, N., Zakuan, N., \& Sulaiman, Z. (2016). The mediating effect of brand image between electronic word of mouth and purchase intention in social media. Advanced Science Letters, 22(10), 3176-3180.

Zhang, J. Q., Craciun, G., \& Shin, D. (2010). When does electronic word-of-mouth matter? A study of consumer product reviews. Journal of Business Research, 63(12), 1336-1341. https://doi.org/10.1016/j.jbusres.2009.12.011

Saraswati, A. R., \& Giantari, I. G. A. K. (2022). Brand image mediation of product quality and electronic word of mouth on purchase decision. International Research Journal of Management, IT and Social Sciences, 9(1), 97-109. https://doi.org/10.21744/irjmis.v9n1.2012 